\title{
Either with us or against us? Third-country alignment with EU sanctions against Russia/Ukraine
}

Elin Hellquist

Freie Universität Berlin and Stockholm University

Abstract Since the mid-1990s, selected neighbours have in impressive numbers aligned with European Union (EU) foreign policy sanctions. However, much more than for any other sanctions case, neighbours have declined joining recent measures against Russia/ Ukraine. This article uses freshly gathered data from the entire period of the Common Foreign and Security Policy (CFSP) to analyse how the practice of alignment influences international relations in Europe. Thereby, the article demonstrates that: (1) sanctions are not a two-party game, but an instrument that impacts broadly on relations with third countries; (2) alignment with sanctions not only articulates similarity, but contributes to normative polarization in wider Europe; (3) for a high-salience case such as Russia sanctions, neighbours are reluctant to be instrumentalized for EU foreign policy purposes. 


\section{Introduction}

Ever since the Euromajdan protests (November 2013) sparked regime change in Ukraine (February 2014), relations between the European Union (EU) and Russia have continuously soured from an already sorry state. The Russian annexation of Crimea (March 2014) and the downing of an MH17 Malaysian Airlines plane on Ukrainian soil (July 2014), as well as the suspected Russian involvement in provoking unrest in Eastern Ukraine (April 2014 - cont.) are the landmark events that have polarized Europe in a way not seen in decades. In the midst of this 'new Cold War', 'Game of Thrones' or 'standoff' (Deutsche Welle 2014; Dolidze 2015; Farchy 2014) are sanctions. The EU has for the first time imposed sanctions against Russia: restrictive measures (asset freezes, travel bans) against individuals and economic sanctions against the sectors of financing, energy and weapons. Russia has answered with retaliatory sanctions on EU agricultural products.

Sanctions have usually been analysed as a secluded affair between two parties: the sender (imposer) and the target (recipient). This article argues that we need to widen the gaze beyond the conventional sendertarget polarity and take seriously the impact of sanctions on relations with 
third countries. Third countries have mainly featured in the sanctions literature insofar as they are considered to be helping or hindering effectiveness, conventionally understood as the target changing its behaviour faced with sanctions. ${ }^{1}$ EU sanctions against Russia and Russian countersanctions provide exemplary evidence that the politics of sanctions is not a two-party game, but a battle over normative belonging in which bystanders play an essential part.

Zooming in on third-country alignment - the formalized practice or 'patterned action' (Adler and Pouliot 2011) where the EU invites selected neighbours to join its sanctions policy-the article places the case of Russia/Ukraine sanctions in the larger context of EU sanctions since the beginning of the Common Foreign and Security Policy (CFSP). For this case, neighbours are resisting EU invitations to align like never before. Likewise, Russia has failed to tie its usual allies to its countersanctions. Non-aligners justify their position in the name of neutrality. However, from the perspective of the EU and Russia, third

\footnotetext{
${ }^{1}$ The view that an effective sanction is one that incites the target to change remains dominant (Giumelli 2011; Hovi et al 2005; Jones 2007). Opinions are split on whether international cooperation helps or hinders target-oriented effectiveness (see Portela 2010, 44, 98-99; Drezner 2000, 73; Miers and Morgan 2002; Hufbauer et al 1990, 95ff; Bapat and Morgan 2009, 1075).
} 
countries do not have the option to be neutral. In the polarized political landscape of EU-Russia sanctions, to not align is taken as an expression of disloyalty.

The presence of sanctions has reawakened slumbering tensions in the entire neighbourhood, complicating political and economic exchanges and contributing to cultural stereotyping. The "clear nervousness' of neighbours (Cardwell 2015) shows that sanctionsputting aside the eternal question of whether they 'work' in the sense of making the target change-are far from empty gestures. Not only do they often have substantial destructive effects on both targets and third countries, they broadly structure international interactions (see Adler and Pouliot 2011, 4). For a Union that still lacks its own military, sanctions can be seen as a substitute for the use of force (on sanctions and war, see George 1991; Baldwin 2000), and alignment with sanctions draws normative boundaries in ways analogous to military alignment.

This research started with a fascination with why neighbours agree to give away their foreign policy initiative to the $\mathrm{EU}$ and commit to sanctioning countries with which they have previously had friendly, if any, relations. That most neighbours suddenly refuse to dance with the EU when it comes to sanctions against Russia/Ukraine adds to the 
'puzzling situation' (Passmore 1962, 107). The aim of this article is to provide an explanation which renders alignment more 'intelligible' (Kratochwil 2008, 456). Rather than searching for a law-like cause behind neighbours' alignment behaviour, the explanatory interest is at the level of how the practice of alignment influences international relations. Hence, the article sets out to answer the following research question:

\section{What does alignment with EU sanctions mean for relations} between the EU, aligning countries and sanctions targets?

Through its emphasis on the social meaning of alignment, the study locates itself in a critical constructivist vein of research (on critical constructivism, see Katzenstein et al 1998; Buzan and Hansen 2009). ${ }^{2}$ Hence, this article does not share the rosy view on norms that has made much constructivism associated with liberal-idealism-utopianism (Barkin 2003). The EU uses alignment as a litmus test of neighbours' normative fidelity, in order to promote its own posture as an international actor (a clearly self-interested, yet ideational, explanation). Alignment becomes

\footnotetext{
${ }^{2}$ A web of different brands of constructivism have emerged, whose respective characteristics are far from mutually exclusive: 'conventional', 'critical', 'consistent', 'thin', 'thick', 'modern', 'postmodern', 'pragmatist ', 'liberal' or 'realist'. This multitude of notions testifies to the fact that constructivism is not a straightforward research paradigm, but rather a set of assumptions about how to study politics (Barkin 2003).
} 
intelligible as an institutionalized practice which communicates value judgments of who is 'good' and 'bad', of belonging and exclusion. This communicative function is called 'normative boundary-drawing'. Material aspects feature in the analysis to the extent that they contribute to the social construction of the practice of alignment, not as isolated independent variables explaining specific policy outcomes (Adler 1997, $322)$.

The article finds that, although invented to communicate continental harmony, the norm of third-country alignment has highly divisive consequences for inter- national relations (see Buzan and Hansen 2009, 197). According to the interpretation advanced in this article, alignment is a communicative act that sends out a message of disapproval to the target of sanctions, and a message of support to the EU as initiator. These messages take political shape through the deed that follows from the alignment declaration: the actual implementation of the sanction finalizes the act of normative boundary-drawing. To join what the Kremlin calls 'anti-Russian sanctions' is an extremely sensitive matter for most neighbours, precisely because the social meaning of this choice surpasses the issue of Ukraine's territorial integrity to characterize Russia as a rogue. For other sanctions cases, especially those targeting democracy or 
human rights violators in Africa, alignment is a convenient way for neighbours to showcase their normative similarity to the EU, and difference to distance 'others'.

The normative boundary-drawing that comes with joining sanctions is distinct from the reasons why individual countries align or not. ${ }^{3}$ To exemplify, regardless of whether Serbia's non-alignment with sanctions against Russia/Ukraine is motivated chiefly by economic self-interest or by cultural identification with a fellow Christian-orthodox country, the choice made carries normative implications for relations with the EU and Russia. Likewise, Albania's perfect alignment score has relational consequences, whether it aligns out of genuine care about international law, or in search of benefits in its relations to the EU. As a parallel, when a US presidential candidate is endorsed by a fellow politician, this decision may stem from shared values or from self-interest, or often a combination of both (for one example, see Gass 2016). In either case, the

\footnotetext{
${ }^{3}$ For the case of third-country alignment, instrumental and norm-guided behaviour do not easily disentangle (Hurd 2010, 310; cf March and Olsen 1998). The alignment procedure reflects the EU's ideas about conditionality, which assume incentive-thinking on the part of the participants (Schimmelfennig and Sedelmeier 2004). At the same time, it privileges the EU's policy position as a normative benchmark, which third countries are expected to follow without having their own say (see Fearon and Wendt 2002, 60 on choices in tight 'webs of norms and roles')
} 
act of endorsement is a declaration of normative support with the candidacy. In the same way, alignment declares normative distance to the target and proximity to the sender of sanctions regardless of the reasons underpinning that decision.

The article proceeds in three steps. First, I introduce the unique practice of alignment with EU sanctions and how it has evolved since the beginning of the CFSP. Thereafter, in the second section I locate the alignment record for Russia/ Ukraine sanctions in the broader picture of third-country alignment with sanctions for the entire duration of the CFSP. The third section discusses the failure of both the EU and Russia to tie their expected allies to their respective sanctions. The paper concludes by considering which lessons we can draw from alignment for understanding sanctions.

\section{Sanctions-breaking the sender-target polarity}

Sanctions have made an astonishing comeback from being deeply delegitimized as genocidal (Bisharat 2001; cf Gordon 2002), unethical (Gordon 1999; Gordon 2010), and ineffective (Pape 1997; Pape 1998; cf Hufbauer et al 1990; Elliott and Hufbauer 1999) by the end of the 1990s, to again dictate the management of the most pressing crises in world 
politics. In the EU's CFSP, highly politicized sanctions cases against Iran,

Russia and Syria have in recent years co-resided with less known but long-running sanctions packages against, for instance, Belarus, Zimbabwe and Transnistria. ${ }^{4}$ Since the beginning of the CFSP in the mid1990s, the EU has asked third countries to publicly declare their support of sanctions. Such alignment with CFSP sanctions is a highly formalized practice (a 'patterned action') of European politics (Adler and Pouliot 2011), which provides an exquisite laboratory for investigating the role of bystanders in the politics of sanctions.

\section{Introducing third-country alignment}

Alignment with sanctions is communicated in a separate declaration from the High Representative of the CFSP (before 2010, from the Presidency of the Council), which is published in a press release. ${ }^{5}$ The declaration has a standardized form where the Council decision(s) in

\footnotetext{
${ }^{4}$ In all these cases of so-called 'autonomous' sanctions, or 'restrictive measures' with a foreign policy dimension (European Commission 2008), the EU is acting without the authorization of the United Nations (UN); the prime designated sender of sanctions under international law (see White and Abass 2010).

5 For legal reasons, alignment with council decisions/common positions needs to be communicated in a separate document. Alignment with CFSP declarations is included at the end of the declaration itself.
} 
question is presented, followed by an enumeration of aligning countries categorized according to their relational status to the EU. The following example is from Press Release 8937/1/14 REV1, PRESSE 235, where five countries declare to align with Council Decision 2014/145/CFSP:

On 17 March 2014, the Council adopted Council Decision 2014/145/CFSP.

The Council Decision imposes a travel ban and asset freeze against persons responsible for actions which undermine or threaten the territorial integrity, sovereignty and independence of Ukraine.

The Candidate Countries Montenegro* and Iceland+, the Country of the Stabilisation and Association Process and potential candidate Albania, and the EFTA [European Free Trade Association] country Norway, member of the European Economic Area, as well as Ukraine have aligned themselves with this declaration.

They will ensure that their national policies conform to this Council Decision.

The European Union takes note of this commitment and welcomes it.

${ }^{1}$ Published on 17.3.2014 in the Official Journal of the European Union No. L 78, p. 16.

* Montenegro continues to be part of the Stabilisation and Association Process.

+ Iceland continues to be a member of EFTA and of the European Economic Area.

The basic form of communication stays the same throughout the years. The countries promise to "ensure that their national policies conform to this Council Decision', and the EU 'takes note of this commitment and welcomes it'. This writing indicates the stronger obligation that comes with alignment with a council decision, in comparison to CFSP declarations which only express shared objectives (on the 'growing obligatory character' of CFSP alignment, see Mayer 2014). ${ }^{6}$

\footnotetext{
${ }^{6}$ This article is interested in alignment as an institutionalized declaratory practice, and does not deal with the question whether third countries live up to their commitments in actual politics.
} 
Some declarations stack triple declaratory layers in the statement: there is a declaration from the High Representative which declares that the third country has declared to commit to follow a council decision of sanctions. However, alignment with sanctions is not only declaratory-it also calls out for something to actually be done. When committing to EU sanctions, third countries 'undertake to align their legal systems to enable the freezing of assets, limitation of trade or impose travel bans on officials' (Cardwell 2015, 307). Existent studies see alignment with the CFSP as a way for the EU to "strengthen its voice in regional and global affairs' (Mayer 2014, 1680; see also Barbé, Costa, Herranz, et al 2009, 839; Barbé, Costa, Surrallés, et al 2009, 383; Törő 2010, 331; Dimitrova and Dragneva 2009, 862-863; Marciacq and Jaramillo 2015, 204). Sometimes the aligning countries have had limited political and economic contact with the target already prior to sanctions. However, even if there is no trade to cut, assets to freeze, or high-level visits to cancel, the 'declarative act of political commitment' communicates normative proximity with the EU and distance to the target (Barbé, Costa, Herranz, et al 2009, 383).

In a rare contribution dealing with EU sanctions, Cardwell calls alignment a 'success' and 'opportunity for wider leadership in the 
European neighbour- hood' (Cardwell 2015, 304). However, where Cardwell $(2015,309)$ sees alignment as the building block for a truly continental European foreign policy, with 'a strong potential to meet the goals of the sanctions, and hence the CFSP itself', this study is more cautious. Just as for sanctions in general, consider- able efforts are put into making measures more harmful, but there is rarely a qualified idea of how they would operate to make the target change (Jones 2015). Rather than fixing this fundamental flaw, alignment instrumentalizes neighbours for the EU's purpose of increasing international posture. By aligning, third countries agree to enter a state of antagonism with a large share of the world's countries.

This equation would not have worked out had there not been a norm to align. EU standpoints have earned a status of 'default positions' that are ‘endowed with normative supremacy’ (Marciacq and Jaramillo 2015, 213, 208). The alignment process leaves no room for consultation. Alignment takes place within 'a clear hierarchical relation' (Barbé, Costa, Herranz, et al 2009, 383), where the neighbour is invited to join already finalized decisions (Marciacq and Jaramillo 2015, 208-209). ${ }^{7}$ When materialized,

\footnotetext{
${ }^{7}$ In the period before accession, candidate countries can participate in the CFSP, though they still cannot take part in the actual decisions (Regelsberger 2003, 5-6). According to Regelsberger, the
} 
alignment implies a hand-over of agency, where the third country grants the EU a right to 'speak on [its] behalf' (Marciacq and Jaramillo 2015, 203-204). ${ }^{8}$ This set-up can be seen as a routinized 'ascendancy over nonEU Europe' (Marciacq and Jaramillo 2015, 216), or even a case of ‘indirect imperial control’ (Dimitrovova 2012, 252).

The institutionalized practice of alignment closes the option of neutrality for anyone included in the universe of invited countries. Invited third countries that choose not to align remain relevant for the sanctions policy as dissidents. This means that it is not only the materialized alignment declarations that draw normative boundaries; declined invitations do as well, but in the opposite direction. Notably, for no single case or period of the CFSP is the full alignment potential reached.

\section{The evolution of alignment}

After having been coordinated at the European level for decades, the European Communities started using non-United Nations (UN)-

\footnotetext{
alignment record of the Central and Eastern European Countries (CEEC) improved a lot once they were permitted in as 'active observers' (from 17 April 2003).

${ }^{8}$ The EU, the US, Canada, Japan and Australia often use sanctions in the same situations. Yet they do not 'align' with each other's policies, but keep parallel policies as independent foreign policy actors.
} 
mandated or 'autonomous' sanctions already in the early 1980s (Portela 2010, xiii). The possibility for candidate states to join EU statements started with the CFSP in 1994. From 1997 onwards, alignment was 'routinized' in the context of enlargement talks with Estonia, Cyprus, Poland, Slovenia, Czech Republic and Hungary (Marciacq and Jaramillo 2015, 206). The members-to-be interpreted alignment in line with the “"return to Europe" narrative' and 'responded enthusiastically' to invitations (Baun and Marek 2013, cited in Marciacq and Jaramillo 2015, 207; Marciacq and Jaramillo 2015, 206). The alignment practice has evolved to include a diverse group of countries that have no contractual obligation to side with the EU's foreign policy. Figure 1 depicts how the universe of countries that are in principle available for alignment has changed as a function of enlargement and developments in the neighbourhood policies. ${ }^{9}$

\footnotetext{
${ }^{9}$ Systematic data on which countries are invited to align with each sanctions case is not publicly available. The EU sometimes circumvents the risk of dissent by not inviting third countries to align with topics it knows are sensitive (Barbé, Costa, Herranz, et al 2009, 391; see also Marciacq and Jaramillo 2014, 7; Dimitrova and Dragneva 2009). It is possible that countries do not appear in specific alignment declarations simply since they were not invited.
} 
Figure 1. The pool of aligning countries.

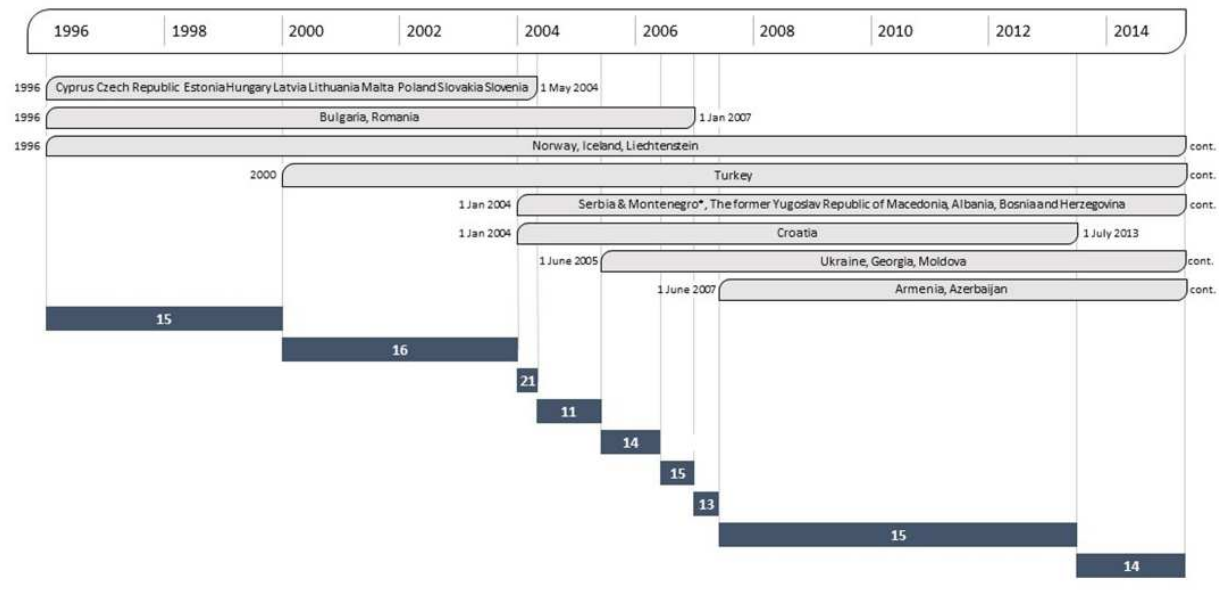

* From mid-June 2006 onwards, Serbia and Montenegro are two independent states and align separately.

A total of 28 countries are in some period part of the pool of aligning countries. For our interest in how alignment with sanctions draws normative boundaries, it is already noteworthy who is included in the pool at different points in time. Membership in the pool, it is argued, reflects the EU's view on who belongs potentially in the EU's normative sphere. The EU categorizes aligning neighbours in 'different circles’ (Törő 2010, 331), in the (evolving) capacities of 'acceding country', 'candidate country', 'potential candidate', 'Country of the Stabilisation and Association Process', 'EFTA-country', or simply uncategorized neighbour. Neither southern neighbours in the European Neighbourhood Policy (ENP), nor other 'partners', such as the members of the African 
Union (AU), are asked to formally align with CFSP sanctions (interviews, AU Headquarters, Addis Ababa December 2010). ${ }^{10}$ Seen within the broader neighbourhood policies, alignment with sanctions communicates not only proximity and belonging to loyally participating countries, but equally distance and difference to non-invited neighbours. According to Barbé et al, the EU avoids 'visualiz[ing]' discrepancies that may cast doubt on its normative authority by limiting the group of invitees to those who are likely to willingly align (Barbé, Costa, Herranz, et al 2009, 391).

Sanctions usually pin powerful, (post-)industrial countries against less powerful, developing countries (see table in Hufbauer et al 1990, 460). Third-country alignment with EU sanctions tells another story. Table 1 shows that countries that are relatively poor, have moderate development scores and are not western-style liberal-democracies become senders of sanctions through alignment with the EU. Apart from the EFTA countries Norway, Iceland and Liechtenstein, the gross domestic product (GDP) of the countries in the alignment pool is below the EU average, and the same goes for their 'Human Development Index'

\footnotetext{
${ }^{10}$ In 2007, a possibility to align with the CFSP on a case-by-case basis was presented to Morocco and discussed for other Mediterranean partners, but it has not been concretized (Council of the European Union 2007a, 2007b).
} 
(HDI). Only four out of 14 countries qualify as 'free', to be compared with the EU-28 where all members are judged 'free'. That 'partly free' countries dominate the group tells us that alignment in most cases does not reflect already existing shared values. Moreover, the lower GDP and HDI indicates that capabilities (material resources) may not be 'the most important determinant of a third party's alignment choices' when it comes to EU sanctions (Corbetta 2010, 72).

Table 1. Basic characteristics of countries in the alignment pool

\begin{tabular}{|c|c|c|c|}
\hline & GDP/capita* & $\begin{array}{l}\text { Human Development } \\
\text { Index** }\end{array}$ & $\begin{array}{l}\text { Freedom } \\
\text { Index } * * *\end{array}$ \\
\hline Armenia & $\$ 8,400$ & 0.733 & Partly Free \\
\hline Liechtenstein & $\$ 89,400$ & 0.908 & Free \\
\hline Norway & $\$ 68,400$ & 0.944 & Free \\
\hline Iceland & $\$ 46,600$ & 0.899 & Free \\
\hline Azerbaijan & $\$ 18,700$ & 0.751 & Not Free \\
\hline Montenegro & $\$ 15,700$ & 0.802 & Partly Free \\
\hline Turkey & $\$ 20,500$ & 0.761 & Partly Free \\
\hline Moldova & $\$ 5,000$ & 0.693 & Partly Free \\
\hline Georgia & $\$ 9,500$ & 0.754 & Partly Free \\
\hline Ukraine & $\$ 8,000$ & 0.747 & Partly Free \\
\hline Bosnia \& & $\$ 10,200$ & 0.733 & Partly Free \\
\hline \multicolumn{4}{|l|}{ Herzegovina } \\
\hline FYR Macedonia & $\$ 14,000$ & 0.747 & Partly Free \\
\hline Albania & $\$ 11,900$ & 0.733 & Partly Free \\
\hline Serbia & $\$ 13,600$ & 0.771 & Free \\
\hline European Union (28) & $\$ 37,800$ & $0,866^{* * * *}$ & All Free \\
\hline \multicolumn{4}{|c|}{$\begin{array}{l}\text { GDP: gross domestic product. } \\
* \text { data from CIA 'The World Factbook', https://www.cia.gov/library/publications/resources/the-world- } \\
\text { factbook/ (accessed } 8 \text { April 2016). All data } 2015 \text { est., apart from Liechtenstein } 2009 \text { est. } \\
\text { ** data from UNDP, Human Development Index for 2014, Human Development Report 2015, } \\
\text { http://hdr.undp.org/en/composite/HDI (accessed } 8 \text { April 2016). } \\
* * * * \text { data from Freedom House 2016, https://freedomhouse.org/report/freedom-world/freedom-world-2016 } \\
\text { (accessed } 8 \text { April 2016). } \\
\text { **** 26/28 EU members rank as having a 'very high level of human development'. Highest score: Denmark } \\
0,923 \text {, lowest score Bulgaria 0,782. }\end{array}$} \\
\hline
\end{tabular}


Table 2 displays the alignment record for all CFSP sanctions cases (1996 - March 2016) for which alignment declarations have been produced. ${ }^{11}$

11 Although the data collection has been cross-checked with different sources, it cannot be established with full certainty that each single alignment declaration has been located, especially for the first few years of the CFSP. In her examination of pre-accession alignment with the CFSP for CEECs, Regelsberger reasons about how irregular alignment practices may be related to 'working practices' within the EU. Until the procedure was standardized in 1999, whether the CFSP texts reached the CEECs at all 'depended on whether the presidency, and the SecretariatGeneral assisting it, understood alignment policy as an important duty at all' (Regelsberger 2003, 5). Deviances may also occasionally result from errors in the alignment declarations themselves. When there are several press releases for the same alignment occasion, I have used the latest revised version. 
Table 2 Alignment Frequency CFSP 1996-March 2016*

\begin{tabular}{|c|c|c|c|c|c|}
\hline & $\begin{array}{l}\text { Date of first and } \\
\text { last/most recent } \\
\text { alignment } \\
\text { declaration, } \\
\text { (number of } \\
\text { declarations } \\
\text { within } \\
\text { parentheses) }\end{array}$ & $\begin{array}{l}\text { Average no } \\
\text { of countries } \\
\text { aligning } \\
\text { (rounded } \\
\text { off to } \\
\text { closest half } \\
\text { unit) }\end{array}$ & $\begin{array}{l}\% \text { of } \\
\text { countries } \\
\text { in pool } \\
\text { aligning } \\
\text { (average } \\
\text { for } \\
\text { entire } \\
\text { period, } \\
\text { rounded } \\
\text { off to } \\
\text { closest } \\
\text { half per } \\
\text { cent) }\end{array}$ & $\begin{array}{l}\text { No of } \\
\text { countries } \\
\text { aligning } \\
\text { with all } \\
\text { applicable } \\
\text { Council } \\
\text { Decisions } \\
\text { (Common } \\
\text { Positions) }\end{array}$ & $\begin{array}{l}\text { No of } \\
\text { countries } \\
\text { aligning } \\
\text { with at } \\
\text { least one } \\
\text { Council } \\
\text { Decision } \\
\text { (Common } \\
\text { Position) }\end{array}$ \\
\hline Afghanistan & 1996-2012 (7) & 13 & $85 \%$ & 21 & 25 \\
\hline Burma/Myanmar & $1996-2015(28)$ & 13 & $85,5 \%$ & 15 & 26 \\
\hline Ex-Yugoslavia** & $1997-2015$ (35) & 12,5 & $85 \%$ & 11 & 28 \\
\hline Belarus & $1998-2015(22)$ & 8 & $56 \%$ & 11 & 20 \\
\hline Indonesia & $1999(1)$ & 14 & $93 \%$ & 14 & 14 \\
\hline Libya & $1999(1)$ & 11 & $73,5 \%$ & 11 & 11 \\
\hline Eritrea/Ethiopia & $1999-2000(3)$ & 15,5 & $98 \%$ & 15 & 16 \\
\hline Counterterrorism & $2002-2012(23)$ & 13 & $83 \%$ & 16 & 28 \\
\hline Zimbabwe & $2002-2016$ (17) & 12,5 & $83 \%$ & 20 & 28 \\
\hline Transnistria & 2003-2015 (10) & 10,5 & $72,5 \%$ & 19 & 27 \\
\hline Sudan/South Sudan & 2004-2014 (3) & 13,5 & $78 \%$ & 21 & 26 \\
\hline Uzbekistan & $2005-2008(4)$ & 11,5 & $79,5 \%$ & 12 & 14 \\
\hline Congo & $2009-2012(2)$ & 11,5 & $76,5 \%$ & 9 & 14 \\
\hline Guinea & $2009-2015(7)$ & 12 & $82,5 \%$ & 8 & 14 \\
\hline Eritrea & $2010(2)$ & 9 & $60 \%$ & 8 & 10 \\
\hline North Korea & $2010-2015$ (5) & 10 & $70 \%$ & 7 & 12 \\
\hline Ivory Coast & 2011-2015 (9) & 12,5 & $83 \%$ & 8 & 14 \\
\hline Somalia & $2011-2012(2)$ & 12 & $80 \%$ & 11 & 13 \\
\hline Libya & 2011-2014 (11) & 11 & $72,5 \%$ & 6 & 14 \\
\hline Syria & $2011-2016(20)$ & 9,5 & $65,5 \%$ & 7 & 12 \\
\hline Iran & 2011-2013 (8) & 9 & $58,5 \%$ & 7 & 11 \\
\hline Egypt & $2011-2015$ (4) & 9 & $60 \%$ & 7 & 11 \\
\hline Tunisia & $2011-2016(5)$ & 10 & $71 \%$ & 9 & 13 \\
\hline Burundi & $2015(1)$ & 10 & $71,5 \%$ & 10 & 10 \\
\hline Average & & 11,5 & $77 \%$ & 12 & 17 \\
\hline \multirow[t]{2}{*}{ Russia /Ukraine } & $2014-2015(23)$ & 5,5 & $40 \%$ & 2 & 8 \\
\hline & $n=253$ & & & & \\
\hline
\end{tabular}

*Sources: EU Council and EU Commission data bases; Bulletins of the European Union (19962009) (http://ec.europa.eu/archives/bulletin/en/bullset.htm); 'Archive of European Integration', University of Pittsburgh (http://aei.pitt.edu/). All calculations are from the author.

** Includes measures concerning the FRY/Serbia, FYROM/Macedonia, International Criminal Tribunal for Yugoslavia, Milosevic, Kosovo, Bosnia and Herzegovina. 
The data shows that for all CFSP sanctions cases for which alignment declarations have been identified, on average 77 per cent of the potential aligning countries have joined EU sanctions. However, alignment numbers vary between cases. Most strikingly, only 40 per cent (on average, for all occasions) of the alignment potential is reached for Russia/Ukraine sanctions. All four sanction regimes against Russia/Ukraine score considerably below average. For the broader economic sanctions against Russia (2014/512/CFSP and amendments), the alignment outcome is only 34 per cent. During the approximate period of sanctions against Russia/Ukraine (2014 - March 2016), the average alignment rate for all other cases is 69 per cent. All 14 countries align at some point during this time, with sanctions against Guinea (12 and 13 aligning countries) gathering the most support. This shows that although few countries in the current pool have a realistic member- ship prospect, the changed composition of the universe of alignees cannot fully account for the drop in alignment in the case of sanctions against Russia/Ukraine. Instead, the low alignment level for Russia/Ukraine amplifies a general tendency: third countries are less inclined to side with sanctions against countries that are geographically close; likely because these countries are considered close also in other respects. For cases in the extended 
European neighbourhood (that is, countries with a border either to an EU country or to a country in the alignment pool), alignment stops at 63.5 per cent on average if the outlier case ex-Yugoslavia ${ }^{12}$ is removed from the calculation. In a nutshell, neighbours privilege vicinity and penalize remoteness in their alignment choices.

However, even in comparison to other 'near' sanctions cases, alignment with Russia/Ukraine measures is low. In the following, this case is analysed in more detail.

\section{Sanctions against Russia/Ukraine}

Long before the Ukraine crisis, EU policy towards Russia was a known source of disagreement within the Union. Sanction enthusiasts (especially within the European Parliament) promoted a tough line on Russia for years, and especially during the wars in Chechnya and Georgia. However, before the annexation of Crimea, sanctions were seen as politically unrealistic in light of the cultural bonds and economic interests of some members towards Russia. ${ }^{13}$ For most of its lifespan, EU sanctions policy

\footnotetext{
12 Most declarations concerning ex-Yugoslavia were made during the years when the alignment pool was made up by countries on the way to membership, and EFTA countries.

${ }^{13}$ During the Chechnya war, the EU did cut aid to Russia within the Technical Assistance to the
} 
has targeted norm violations in the field of democracy and human rights, taking place in developing countries (Portela 2010, 172). That the 28 members of the EU could agree to impose sanctions against such a big and resourceful country as Russia came as a surprise to many.

Sanctions in reaction to the Ukraine crisis first took the usual form of targeting a number of Ukrainian and Russian individuals with asset freezes and travel bans, and have gradually expanded to include economic sanctions against Russia and Crimea/Sevastopol. From March 2014, two groups of individuals were targeted in separate Council decisions: (i) politicians and high officials deemed responsible for misappropriation of Ukrainian state funds and human rights violations (2014/119/CFSP $),{ }^{14}$

Commonwealth of Independent States (TACIS) programme (Haukkala 2010, 118).

14 Council Decision 2014/119/CFSP targeted 18 individuals, including former President Yanokovych and two of his sons, and four persons were added on 14 April 2014 (Council Implementing Regulation No. 381/2014). All individuals were designated on the basis that they are 'subject to criminal proceedings' or 'subject to investigation' in Ukraine, as indicated by information given by the new regime in Kiev ('a letter from March 2014 from the office of Ukraine's Prosecutor General', Lester and O'Kane 2016). Many of the individuals accused of misappropriating funds have challenged the sanctions at the European Courts, and all six judgments so far have annulled their listings due to lacking evidence (EUR-Lex 2016; Lester and O'Kane 2016). However, as is common procedure, the Council had already relisted some of them referring to new criteria (2015/364/CFSP) which will be tried in new Court cases (see Norman 2014, 2016). In March 2016, Council Decision 2016/318/CFSP and Council Implementing Regulation (EU) 2016/311 renewed the listing of 16 persons, and lifted the sanctions against one person reported to have paid back the funds she was accused of misappropriating. 
and (ii) militaries and high officials from Russia and from the new administration in Crimea deemed responsible for undermining or threatening the territorial integrity of Ukraine (2014/145/CFSP). ${ }^{15}$

As the conflict with Russia intensified, the EU added sanctions that aim at inflicting broad economic harm. ${ }^{16}$ Concerning Crimea and Sevastopol, there is a general import and investment ban, an export ban (including services) on transport, telecommunications, energy and natural resources, and a prohibition on EU tourism services (including cruise ships) (European External Action Service 2015, see Council Regulation 1351/2014). When it comes to Russia, financial exchanges and services (including providing loans) are forbidden with 'five major state-owned Russian banks, their subsidiaries outside the EU and those acting on their behalf or under their control..., three major Russian energy companies and three major Russian defence companies'. There is also a two-way arms embargo, a 'prohibition

\footnotetext{
${ }^{15}$ 2014/145/CFSP first listed 21 politicians, militaries and high officials from Russia and from the new administration in Crimea who were listed for undermining or threatening the territorial integrity of Ukraine. After repeated amendments, in September 2015139 individuals and 37 entities were subject to targeted sanctions under this decision (Council of the European Union 2015).

${ }^{16}$ Notably, the EU itself distinguishes between diplomatic measures, restrictive measures and economic sanctions on its information site (European External Action Service 2015). This departs from the previous insistence that all EU sanctions are 'targeted'; that is, that they aim at inflicting harm only on responsible individuals or specific sectors linked to a norm violation.
} 
on exports of dual use goods and technology for military use in Russia or to Russian military end-users', and exports of 'certain energy-related equipment and technology ... are subject to prior authorization' (European External Action Service 2015). Moreover, the Council has asked the Commission to reconsider cooperation programmes with Russia, which can be suspended on a case-to-case-basis. In sum, the broad package of measures against Russia hits crucial economic sectors (energy, arms, financial services) and is likely to have contributed to the collapse of the rouble and the general economic crisis (Birnbaum 2015; Foy 2015; Bosworth 2014; Boghani 2015). ${ }^{17}$

On 6 August 2014, Russia announced retaliatory sanctions (President of the Russian Federation 2014), which were concretized the following day to refer to 'agricultural produce, raw materials and food products that originate in the US, the EU, Canada, Australia and Norway (The Russian Government 2014). One year later, countersanctions were extended to Iceland, Montenegro, Liechtenstein, Albania and Ukraine (The Russian Government 2015). Commenting on this decision, Russian Prime Minister Dmitry Medvedev argued that neighbours were simply reaping

\footnotetext{
17 This does not mean that Putin will change his policy because of sanctions. On the contrary, sanctions may provide a convenient scapegoat for the Russian regime, along the classical pattern of comprehensive sanctions (Galtung 1967).
} 


\section{what they had sown:}

These countries joined the European Union's decision to extend the anti-Russian sanctions. They explain their decision by the fact that they are obliged to impose these sanctions due to various kinds of agreements with the European Union, but this position is only partly true. A number of states that have similar agreements with the EU have not adopted the anti-Russian sanctions.

Therefore, joining the sanctions is a conscious choice, which shows their readiness for Russia's response.

Figure 2 summarizes the main events and the principal sanctions decisions from November 2014 until August 2015. The original four decisions have been continuously amended, producing a total of 23 alignment declarations referring to 27 council decisions.

Figure 2. Timeline sanctions.

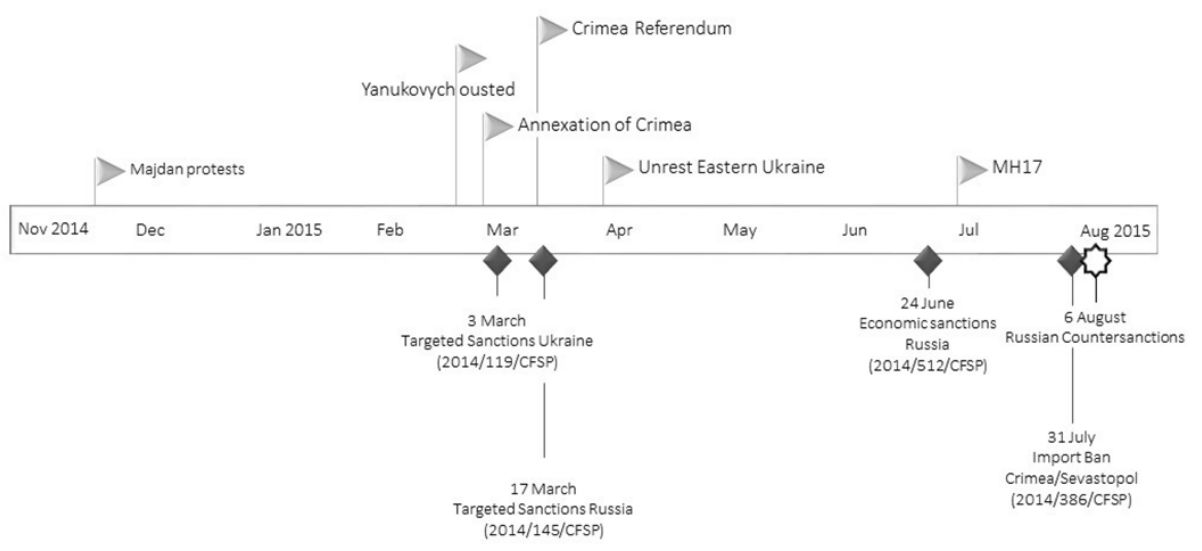




\section{Alignment and normative boundaries}

A conflict with as 'high [a] level of hostility' as the one currently enrolling between the EU and Russia over the crisis in Ukraine has "politicostrategic repercussions that ripple across the international system, affecting potential third parties' (Yamamoto and Bremer 1980, cited in Corbetta 2010,71). That third countries are affected by the conflict does not, however, mean that they wish to formally align with either of the protagonists. As we can see from Table 2, the number of countries aligning with EU sanctions in Russia is considerably lower than for any other CFSP sanctions case. Likewise, as will be discussed in the third section of this article, Putin has failed to gather support for his countersanctions from his allies in the Eurasian Union.

Fourteen countries in total are part of the universe of possible aligning countries at the point of sanctions against Russia: Serbia, Turkey, Montenegro, Albania and Former Yugoslav Republic (FYR) Macedonia as candidate states; Norway, Liechtenstein and Iceland ${ }^{18}$ as EFTA members; Bosnia and Herzegovina as a country of the Stabilisation and Association Process and potential candidate; and Moldova, Georgia,

\footnotetext{
${ }^{18}$ On 12 March 2015, Iceland withdrew its candidacy to become a member of the EU.
} 
Azerbaijan, Ukraine and Armenia as uncategorized neighbours. They aligned after having been invited by the EU, and 'on the basis of some form of agreement concerning involving consultation and collaboration on CFSP policies' (author's e-mail correspondence, European External Action Service (EEAS), 6 May 2015). ${ }^{19}$ It has not been possible to access the invitations themselves, but according to a high-ranking official at the EEAS, these 14 countries 'are as a rule requested to align to EU sanctions decisions' (author's e-mail correspondence EEAS, 6 May 2015).

As can be seen from Figure 3, a total of eight countries have at some point aligned with EU sanctions against Russia, while six countries never aligned. The average number of aligning countries per declaration is between five and six, out of a maximum of 14 countries on each occasion.

\footnotetext{
${ }^{19}$ Ukraine aligned with EU CFSP acts between 2000 and 2005 on its own initiative. However, the EU did not communicate any Ukrainian alignment declaration with sanctions for this period.
} 
Figure 3. Alignment with Russia/Ukraine sanctions.

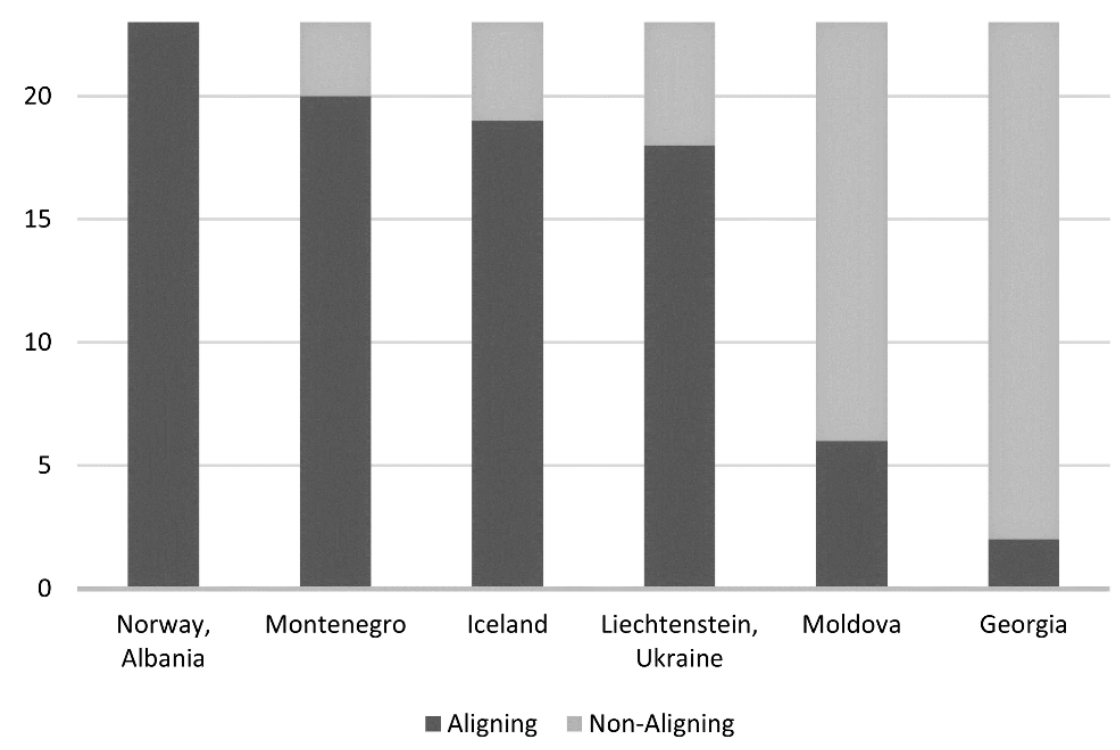

Only Norway and Albania have aligned on all 23 occasions. They both see alignment with EU sanctions as a matter of siding with their allies (see Verdens Gang 2014; Brende 2015; Reuters 2014; Albanian Telegraphic Agency 2014). Norway was the only of the aligning countries to be included in the first Russian decision on agricultural countersanctions (The Russian Government 2014). Albania was included in the second package of countersanctions in 2015, but already in 2014 Russia expressed regret over its decision to join sanctions and accused it of re-exporting banned products from the EU (Independent Balkan News Agency 2014; Sputnik 2014). By contrast, EU representatives rejoice over 
Albania's 100 per cent alignment record with the CFSP in general, and with sanctions against Russia in particular (European Commission 2014c). To give one example, upon meeting with Albanian Prime Minister Edi Rama in February 2015, EU Council President Donald Tusk took the occasion to 'commend Albania for its 100 per cent alignment with EU policy in foreign affairs', which 'is of real significance for the enlargement process, and even more so now given the situations in Ukraine' (Tusk 2015).

Iceland, Montenegro, Ukraine, Liechtenstein, Moldova and Georgia have aligned with some, but not all, council decisions. Figure 4 displays alignment divided by the four sanctions packages imposed in reaction to the Ukraine crisis. 
Figure 4. Partial aligners and sanctions type.
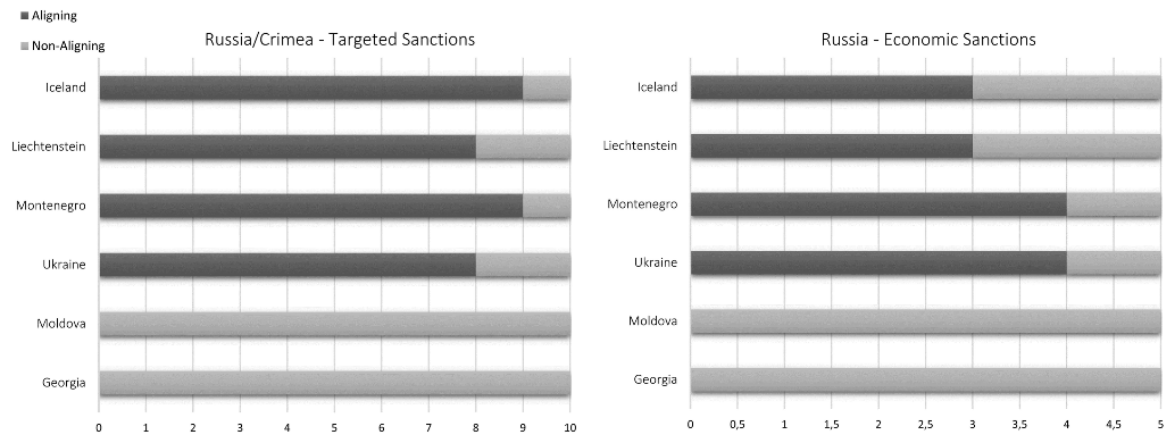

Crimea/Sevastopol - Investment Ban

Ukraine Targeted Sanctions - Misappropriation
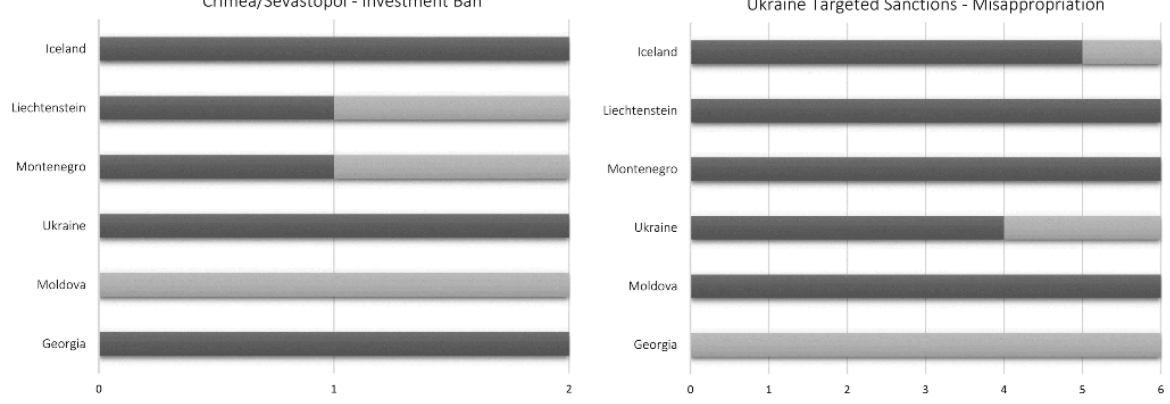

The tailored alignment patterns demonstrated in Figure 4 suggest that (non-) alignment has not been made out of pure habit or sense of contractual obligation towards the EU. Since the EU's different sanctions vary in both normative and material content, it is not senseless to reject some alignment invitations and accept others. It is, for instance, entirely feasible to agree with targeted measures against individuals while being critical of broader economic sanctions (or the other way around). For Moldova and Georgia, such a logic of consistent alignment with specific council decisions can be seen. Moldova has aligned on all six 
occasions with measures concerning the misappropriation of state funds from the former Ukrainian government, but is missing from all other alignment declarations. In spite of its pronouncedly pro-western foreign policy (see Giragosian 2014; Gasanova 2014), and previous loyal alignment with critical CFSP declarations about Russia (Mayer 2014, 1692), Georgia is only found on the two alignment declarations that concern the import ban on Crimea/Sevastopol. For Montenegro and Iceland, there is no substantive pattern linking the occasions of nonalignment. Instead, Montenegro is only missing from the three declarations published on 20 August 2014. Iceland disappears from four alignment declarations after the 'deeply disappointing' (Ministry for Foreign Affairs Iceland 2015) Russian decision to include Iceland in the second wave of countersanctions. Yet Icelandic politicians ensure that the country's support of EU sanctions has not changed (Iceland Monitor 2016; Iceland Monitor 2015). Finally, Ukraine itself is 'not requested to align ... where sanctions target the situation in Ukraine' (author's e-mail correspondence, EEAS, 6 May 2015); but is nonetheless listed among the aligning countries for four out of six declarations concerning targeted sanctions against the former Ukrainian regime.

Although each country in the group of partial aligners has its own 
alignment profile, they have one thing in common. In terms of normative boundary-drawing, they offer selective support to the EU, rather than a carte blanche approval of its leadership. This goes especially for the countries that have a systematic pattern to their (non)-alignment, as do Moldova and Georgia. The countries that dissent from individual declarations without apparent political reason will be perceived as fully siding with the EU from the Russian perspective. Duma Speaker Sergei Naryshkin has, for instance, talked of how Montenegro's alignment 'causes serious damage to our relations in practically all areas' (Sputnik 2016). The fact that four out of six countries in the second round of countersanctions do not align fully with EU sanctions also testifies to Russia's disinterest in the details of partial alignment.

Lastly, Serbia, FYR Macedonia, Turkey, Azerbaijan, Armenia, and Bosnia and Herzegovina have all completely rejected invitations to join the EU's sanctions against Russia/Ukraine. Most of the non-aligning countries supported the UN General Assembly resolution 68/262 of 23 March 2014 on the territorial integrity of Ukraine (United Nations General Assembly 2014). ${ }^{20}$ This suggests that their non-alignment does

\footnotetext{
${ }^{20}$ Albania, Azerbaijan, Georgia, Iceland, Liechtenstein, Montenegro, Norway, Moldova, Macedonia, Turkey and Ukraine all voted in favour of the Resolution; Armenia voted against;
} 
not follow from disagreement with the EU on the issue itself, but is a rejection of EU leadership and of the appropriateness of using sanctions in this situation.

Non-aligners include three candidate states (Serbia, FYR Macedonia and Turkey), as well as one 'potential candidate' (Bosnia and Herzegovina). Their alignment record is used as an important indicator of their commitment to the European project, and (non-)alignment with sanctions against Russia/Ukraine is mentioned specifically in the progress reports for 2014 (European Commission 2014a, 18; European Commission 2014e, 59; European Commission 2014b, 62; European Commission 2014f, 74; European Commission 2014d, 6). ${ }^{21}$ Even candidates are not obliged to sign on to each foreign policy position of the EU. According to High Representative Mogherini, there is 'a legal obligation of progressive harmonization with EU positions', but 'the EU cannot impose anything' even on candidate countries (Balkan Insight

\footnotetext{
and Serbia and Bosnia and Herzegovina were not present at the vote.

${ }^{21}$ ENP evaluation reports mention general CFSP alignment records with the CFSP, but not alignment with Russia/Ukraine sanctions specifically (European Commission 2015b, 9; European Commission 2015c, 8; European Commission 2015f, 10; European Commission 2015e, 10; European Commission 2015d, 9).
} 
2015; B92 2015a).

\section{Sanctions and the failure of great power politics}

The tensions created by EU sanctions against Russia, and by Russian countersanctions against the EU, have spilled over into the shared neighbourhood. Neither the EU nor Russia has been successful in translating these tensions into broad support from its partners. Sanctions in reply to the Ukraine crisis have been a hard test for the EU's alignment mechanism as well as for Putin's prestige project, the Eurasian Union. Both have failed their tests.

With only Norway and Albania fully committing to EU sanctions, alignment has reached an all-time low. Thereby, a two-decade long legacy of impressive alignment numbers has been broken. Confronted with a sanctions case where there are colliding foreign policy interests, alignment is no longer seen as a 'privilege' or 'opportunity' (Mayer 2014, 1691, 1698). Instead, non-aligners question the premise of alignment, and by extension the EU's conditionality regime (see Marciacq 2014).

With FYR Macedonia's accession process at an 'impasse' 
(European Commission 2014a, 2), ${ }^{22}$ Turkey's negotiations in 'need to regain momentum' (European Commission 2014f, 1), and Bosnia and Herzegovina remaining 'at a standstill on its European integration path' (European Commission 2014a, 2), most of the EU's disappointment has been directed at Serbia (European Commission 2014b, 4; European Parliament 2015). According to Marciacq (2014), '[b]y refusing to align itself with European sanctions against Moscow, Serbia keeps infuriating Brussels'.

Serbian Foreign Minister Ivan Mrkić insists that 'this is not a choice between East and West, nor will Serbia choose according to this pattern' (B92 2014). Russian Foreign Minister Lavrov has praised this attitude, claiming that many European countries 'have the attitude of "either-or"', whereas 'Serbia's position is originally European' (B92 2015b). Simultaneously a 'strategic partner' to Russia and an EU candidate state, Serbian Prime Minister Vucic has questioned expectations of expressing 'solidarity' with the EU (Poznatov 2014):

\footnotetext{
${ }^{22}$ Russian Foreign Minister Lavrov commented on the violence and demonstrations in Skopje in May 2015 as follows: 'it so happens objectively that these events in Macedonia are unfolding against the background of the Macedonian government's refusal to join sanctions against Russia' (Bershidsky 2015; see also Buckley 2015).
} 
Solidarity in what? We were not consulted when sanctions against Russia were introduced, nor when Russia responded by imposing countersanctions. Is it possible that we, who had no part in any of that, are now considered to be responsible by both sides?

Also Turkey has openly contested the logic behind sanctions alignment. In an interview in the German weekly Die Zeit, Foreign Minister Cavusoglu under- lined that Turkey is under no obligation to align with sanctions against Russia/ Ukraine. 'Turkey makes its own decisions', and if it would find sanctions to be necessary, it would take its own measures rather than aligning with the EU (Thumann and Topçu 2015). In a visit to Ankara in December 2014, High Representative Mogherini said that Turkey's historically low alignment with the CFSP needs to be improved: it is 'a problem for the European Union, but it is mainly a problem for Turkey' (Hogg and Karadeniz 2014). Cavusoglu replied by pointing to 'a contradiction of the EU', where Turkey is asked to align while being 'kept out of the decision mechanisms' (Newsweek/Reuters 2014). Before Turkish-Russian relations soured in late 2015, Putin praised 'our Turkish partners [for] refus[ing] to sacrifice their interests for somebody else's political ambitions', speaking of alignment as subordination (Putin 
2014)..$^{23}$

By challenging the passive acceptance of the EU position as the norm, Serbia and Turkey question the asymmetry of the entire enlargement process. Meeting with the other Western Balkan leaders in May 2015, Vucic declared that 'we are fed up with seminars' (EurActiv 2015). Some months earlier, President Erdogan announced that Turkey 'will not come to your door begging for accession' (Dud- ley 2015).

The EU envisages alignment as a prolongation of the allegedly successful use of enlargement as 'a powerful instrument of the Union's external policy'. According to the Commission's 2014 enlargement strategy report, this is especially important in light of '[d]evelopments in the EU's neighbourhood'; also known as the Ukraine crisis (European Commission 2014a, 18). However, the fact that only one candidate country (Albania) has fully joined such an important case as Russia/Ukraine sanctions shows that there are limits as to how far third countries can be instrumentalized for EU foreign policy purposes.

Sanctions have brought about new cleavages also among Russian

\footnotetext{
${ }^{23}$ Turkey has been under Russian sanctions since a Russian military jet was shot down on November 2015. However, Turkey has not imposed any countersanctions, Erdogan calling the Russian measures 'emotional' and not in line with 'state dignity' (Al Arabiya 2015).
} 
partners. None of the Eurasian Economic Union (EEU) members

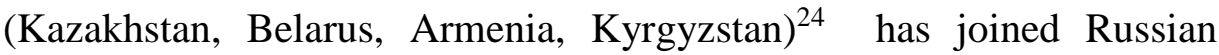
countersanctions (Russell 2016). Rather than bringing the EEU members closer by being faced with a common western enemy, observers speculate about the end of the Union only months after it was inaugurated (Schenkkan 2014). 'Trade war' has broken out between Russia and Kazakhstan (The Moscow Times 2015), and Russia has restricted the import of Belarusian meat and dairy products (Williams 2014). Since the EEU is a customs union, banned European goods can enter Russia via transit countries that have not aligned with Russian countersanctions. Reports from Russia speak of an abundance of relabelled European products on the shelves: 'It's all Belarusian, Belarusian oysters, Belarusian mandarins' (Fresh Plaza 2015). Belarussian President Lukashenka reasons that Belarus should not suffer from 'the reciprocal economic sanctions against America and Europe', since 'we cannot face more sanctions' and '[w]e'd like to get rid of the sanctions that have been

\footnotetext{
${ }^{24}$ Armenia became a member of the EEU on 2 January 2015, and Kyrgyzstan on 8 August 2015 (Eurasian Economic Commission 2015a, 2015b). Even after entering the EEU, Armenia has aligned with several EU sanctions decisions, for instance against Guinea (PRESS RELEASE 871/15) and North Korea (PRESS RELEASE 11/08/2015).
} 
applied to us already' (Pres- ident of the Republic of Belarus 2014). Indeed, most EU sanctions against Belarus were suspended for half a year in October 2015, and thereafter not extended in February 2016 (Council of the European Union 2016). ${ }^{25}$

Moreover, after having cancelled the EU Association Agreement in September 2013, the new EEU member Armenia is back discussing possible forms of cooperation with the EU (European Commission 2015a, 10; European Commission 2015b, 2; Aslanian 2015; Youngs 2015). The pragmatism displayed by these countries does not fit well with the Russian hopes of developing a political Eurasian regionalism (Hancock 2007; Aron 2013; Astapenia 2015).

\section{Conclusion}

For the past two decades, sovereign third countries in wider Europe have in great numbers aligned with EU CFSP sanctions. In a seemingly mutually beneficial exchange, the EU has used alignment to signal the reach of its normative sphere, and neighbours have traded their foreign policy agency for expected benefits in relations to the EU. Like any

\footnotetext{
${ }^{25}$ There is still an arms embargo and targeted sanctions in place against four persons.
} 
norm, the norm of alignment has been contested for individual sanctions cases. For sanctions against Russia/Ukraine, it has collapsed.

A condition for the alignment norm to establish in the first place was that neighbours did not have competing foreign policy interests in the sanctions cases. As long as the EU's sanctions policy mainly targeted individuals accused of human rights and democracy violations in distant countries, alignment was a cheap way for third countries to state normative allegiance with the EU. However, EU sanctions have continuously expanded to become the Union's default policy option for dealing with almost any crisis. In May 2015, more than one-third of the world's population lived in a country which was targeted by EU sanctions (author's calculation). Moreover, in recent years, broad economic sanctions made their way back into international politics through sanctions against Iran, Syria and Russia. For these cases of outstanding weight for global politics, the alignment choices of third countries redraw normative boundaries in a potentially drastic way for the international order.

The stakes of alignment-both for the EU and for the third countries-have culminated with sanctions against Russia/Ukraine. Sanctions have brought friction and confusion to relations in wider 
Europe. This time, neighbours have not collectively joined the EU's exercise of normative boundary-drawing towards Russia. Instead, by resisting aligning, they contest the EU's claim to normative primacy in terms of both its leadership and its policy choice. Alignment with sanctions not only communicates similarities between participating countries, but equally and increasingly 'creates new limits and dividing lines among the neighbours' (Dimitrovova 2012, 250). This outcome has little to do with whether sanctions 'work' in the sense of convincing the target to stop with whatever wrongdoing it is up to.

In conclusion, this study of alignment reveals that the politics of sanctions are a multi-relational battle over normative substance (what is good/bad, who merits punishment) and procedure (who should decide, who should lead). Contestation over these aspects for the case of Russia/Ukraine sanctions elucidate perfectly that "[n]orms are not important because they create harmony ... but because they help us to recognize cleavages and conflicts in a society' (Hall and Kratochwil 1993, 487-488). 
This is an Accepted Manuscript of an article published by Taylor \& Francis in Cambridge Review of International Affairs on 18 October 2016, available online:

http://www.tandfonline.com/https://doi.org/10.1080/09557571.2016.1230591

\section{Funding}

This research was supported by the Swedish Research Council (SRC) and generated in the framework of DFG-supported KollegForschergruppe 'The Transformative Power of Europe' at Freie Universität Berlin. 
This is an Accepted Manuscript of an article published by Taylor \& Francis in Cambridge Review of International Affairs on 18 October 2016, available online:

http://www.tandfonline.com/https://doi.org/10.1080/09557571.2016.1230591

\section{References}

Adler, Emanuel (1997) 'Seizing the middle ground', European Journal of International Relations, $3: 2,319-363$

Adler, Emanuel and Vincent Pouliot (2011) 'International practices', International Theory, 3:1, $1-36$

Al Arabiya (2015) 'Turkey won't retaliate against Russia's sanctions' December 2. <http:// ara.tv/59p74>, accessed 11 April 2016

Albanian Telegraphic Agency (2014) 'Kodheli: Albania stands by Allies in sanctions against Russia', 13 September

Aron, Leon (2013) 'The Putin doctrine', Foreign Affairs, 8 March

Aslanian, Karlen (2015) 'Poland backs EU-Armenia “Association”, Azatutyun, 5 April, <http://www.azatutyun.am/content/article/26994157.html>, accessed 11 April 2016 Astapenia, Ryhor (2015) 'Belarus and the Eurasian Economic Union: The view from

Minsk', European Council of Foreign Relations, 7 January, <http://www.ecfr.eu/article/ commentary_belarus_and_the_eurasian_economic_union_the_view_from_minsk>, accessed 11 April 2016

B92 (2015a) 'President, EU's Mogherini have "Frank conversation"', 27 March, <http:// www.b92.net/eng/news/politics.php?yyyy=2015\&mm=03\&dd=27\&nav_id=93630>, accessed 11 April 2016

B92 (2015b) 'Stable, friendly, fraternal' ties with Russia', <http://www.b92.net/eng/news/ politics.php?yyyy=2015\&mm=05\&dd=15\&nav_id=94138>, accessed 11 April 2016

B92 (2014) 'West wants Serbia to join sanctions against Russia', 28 March <http://www.b92. net/eng/news/politics.php?yyyy=2014\&mm=03\&dd=28\&nav_id=89804>, accessed 11 April 2016

Baldwin, David A (2000) 'The sanctions debate and the logic of choice', International Security, $24: 3,80-107$

Balkan Insight (2015) 'EU's Mogherini tells Serbia to hasten reforms', 27 March, <http:// www.balkaninsight.com/en/article/mogherini-visits-serbia-to-supports-eu-reforms>, accessed 11 April 2016

Bapat, Navin A and T Clifton Morgan (2009) 'Multilateral versus unilateral sanctions reconsidered: a test using new data', International Studies Quarterly, 53:4, 1075-1094

Barbé, Esther, Oriol Costa, Anna Herranz, Elisabeth Johansson-Nogués, Michal Natorski and Maria A Sabiote (2009) 'Drawing the neighbours closer ... to what?: Explaining emerging patterns of policy convergence between the EU and its neighbours', Cooperation and Conflict, 44:4, 378-399

Barbé, Esther, Oriol Costa, Anna Herranz Surrallés and Michal Natorski (2009) 'Which rules shape EU external governance? Patterns of Rule Selection in Foreign and Security Policies', Journal of European Public Policy, 16:6, 834-852

Barkin, J Samuel (2003) 'Realist constructivism', International Studies Review, 5:3, 325-342 Baun, Michael J and Dan Marek (2013) The new member states and the European 
This is an Accepted Manuscript of an article published by Taylor \& Francis in Cambridge Review of International Affairs on 18 October 2016, available online:

http://www.tandfonline.com/https://doi.org/10.1080/09557571.2016.1230591

Union: foreign policy and Europeanization (London: Routledge)

Bershidsky, Leonid (2015) 'Macedonia, the latest US-Russia battlefield', Bloomberg View, 19 May, <http://www.bloombergview.com/articles/2015-05-19/macedonia-the-latest-u- srussia-battlefield>, accessed 11 April 2016

Birnbaum, Michael (2015) 'A year into a conflict with Russia, are sanctions working?' The Washington Post, 26 March. <http://www.washingtonpost.com/world/europe/a- yearinto-a-conflict-with-russia-are-sanctions-working/2015/03/26/45ec04b2-c73c- 11 e4bea5-b893e7ac3fb3_story.html>, accessed 11 April 2016

Bisharat, George E (2001) 'Sanctions as genocide', Transnat'l L. \& Contemp. Probs., 11: 379 Boghani, Priyanka (2015) 'What's been the effect of western sanctions on Russia',

FRONTLINE, 13 January. <http://www.pbs.org/wgbh/pages/frontline/foreign- affairsdefense/putins-way/whats-been-the-effect-of-western-sanctions-on-russia/>, accessed 11 April 2016

Bosworth, Barry (2014) 'Barry Bosworth on the effect of sanctions on Russia's economic slide', Brookings, 3 December, <http://www.brookings.edu/blogs/brookings-now/ posts/2014/12/bosworth-effect-sanctions-russia-economic-slide>, accessed 11 April 2016

Brende, Børge (2015) 'Utenrikspolitisk redegjørelse 5. mars 2015', <http://www.regjeringen.no/nb/aktuelt/redegjorelse_150305/id2398550/>, accessed 11 April 2016

Buckley, Neil (2015) 'Russia accuses west of stirring revolution in Macedonia', Financial Times, 18 May

Buzan, Barry and Lene Hansen (2009) The evolution of international security studies (Cambridge: Cambridge University Press)

Cardwell, Paul James (2015) 'The legalisation of European Union foreign policy and the use of sanctions', Cambridge Yearbook of European Legal Studies, 17:1, 287-310

Corbetta, Renato (2010) 'Determinants of third parties' intervention and alignment choices in ongoing conflicts, 1946-2001', Foreign Policy Analysis, 6:1, 61-85

Council of the European Union (2007a) 'Conclusion of the 2809th Council Meeting', <http://europa.eu/rapid/press-release_PRES-07-138_en.htm>, accessed 11 April 2016 Council of the European Union

Council of the European Union (2007b) 'Sixth meeting of the EU-MOROCCO Association Council - Statement by the European Union', <http://www.consilium.europa.eu/ueDocs/cms_Data/docs/pressData/en/er/95454.pdf>, accessed 11 April 2016 Council of the European Union (2015) 'List of persons and entities under EU restrictive measures over the territorial integrity of Ukraine', <http://www.consilium.europa. eu/en/press/press-releases/2015/09/pdf/150915sanctions-table-persons-and- entities_pdf/>, accessed 11 April 2016

Council of the European Union (2016) 'Belarus sanctions: EU Delists 170 people, 3 companies; Prolongs arms embargo', 25 February, <http://www.consilium.europa. eu/en/press/press-releases/2016/02/25-belarus-sanctions/>, accessed 11 April 2016

Deutsche Welle (2014) 'Former soviet leader Gorbachev warns against "New cold war" in 
Ukraine crisis', 16 October, <http://www.dw.de/former-soviet-leader-gorbachevwarns-against-new-cold-war-in-ukraine-crisis/a-17999860>, accessed 11 April 2016

Dimitrova, Antoaneta and Rilka Dragneva (2009) 'Constraining external governance: Interdependence with Russia and the CIS as limits to the EU's rule transfer in the Ukraine', Journal of European Public Policy, 16:6, 853-872

Dimitrovova, Bohdana (2012) 'Imperial re-bordering of Europe: the case of the European Neighbourhood Policy', Cambridge Review of International Affairs, 25:2, 249-267

Dolidze, Tatia (2015) 'EU sanctions policy towards Russia: The sanctioner-sanctionee's game of thrones', CEPS Working Document No. 402/January 2015

Drezner, Daniel W (2000) 'Bargaining, enforcement, and multilateral sanctions: when is cooperation counterproductive?', International Organization, 54:1, 73-102

Dudley, Dominic (2015) 'Identity crisis: Turkey, Europe, and Erdoğan', Bloomberg Businessweek, 5 March

Elliott, Kimberly Ann and Gary Clyde Hufbauer (1999) 'Same song, same refrain? Economic sanctions in the 1990's', The American Economic Review, 89:2, 403-408

EurActiv (2015) 'Balkan leaders: "We are fed up with seminars", 29 May, <http://www. euractiv.com/section/enlargement/news/balkan-leaders-we-are-fed-up-withseminars/>, accessed 11 April 2016

Eurasian Economic Commission (2015a) 'Armenia is now in the Eurasian Economic Union', 2 January, <http://www.eurasiancommission.org/en/nae/news/Pages/02-01-20151.aspx>, accessed 11 April 2016

Eurasian Economic Commission (2015b) 'Kyrgyzstan acceded to the Eurasian Economic Union', 12 August, <http://www.eurasiancommission.org/en/nae/news/ Pages/12-08-20151.aspx>, accessed 11 April 2016

EUR-Lex (2016) 'Document 32014D0119 (Linked documents to council decision 2014/119/CFSP)', <http://eur-lex.europa.eu/legal-content/EN/ LKD/?uri=CELEX:32014D0119>, accessed 11 April 2016

European Commission (2008) 'European Commission - Restrictive Measures', <http:// eeas.europa.eu/cfsp/sanctions/docs/index_en.pdf>, accessed 11 April 2016

European Commission (2014a) 'Enlargement strategy and main challenges 2014-15', $<$ http://ec.europa.eu/enlargement/pdf/key_documents/2014/20141008-strategypaper_en.pdf $>$, accessed 11 April 2016

European Commission (2014b) 'Serbia progress report', <http://ec.europa.eu/ enlargement/pdf/key_documents/2014/20140108-serbia-progress-report_en.pdf >, accessed 11 April 2016

European Commission (2014c) 'Albania progress report', <http://ec.europa.eu/ enlargement/pdf/key_documents/2014/20141008-albania-progress-report_en.pdf>, accessed 11 April 2016

European Commission (2014d) 'Bosnia and Herzegovina progress report', <http:// ec.europa.eu/enlargement/pdf/key_documents/2014/20141008-bosnia-andherzegovina-progress-report_en.pdf>, accessed 11 April 2016 
European Commission (2014e) 'The former Yugoslav Republic or Macedonia progress report', $<$ http://ec.europa.eu/enlargement/pdf/key_documents/2014/20141008-the- formeryugoslav-republic-of-macedonia-progress-report_en.pdf>, accessed 11 April 2016

European Commission (2014f) 'Turkey progress report', <http://ec.europa.eu/ enlargement/pdf/key_documents/2014/20141008-turkey-progress-report_en.pdf>, accessed 11 April 2016

European Commission (2015a) 'Implementation of the European Neighbourhood Policy in 2014', $<$ http://eeas.europa.eu/enp/pdf/2015/joint-communication_en.pdf〉, accessed 11 April 2016

European Commission (2015b) 'Implementation of the European Neighbourhood Policy in Armenia Progress in 2014 and recommendations for actions', <http://eeas.europa.eu/ enp/pdf/2015/armenia-enp-report-2015_en.pdf>, accessed 11 April 2016

European Commission (2015c) 'Implementation of the European Neighbourhood Policy in Azerbaijan progress in 2014 and recommendations for actions', <http://eeas.europa. eu/enp/pdf/2015/azerbaijan-enp-report-2015_en.pdf>, accessed 11 April 2016

European Commission (2015d) 'Implementation of the European Neighbourhood Policy in Georgia progress in 2014 and recommendations for actions', <http://europa.eu/ rapid/press-release_MEMO-15-4686_en.pdf>, accessed 11 April 2016

European Commission (2015e) 'Implementation of the European Neighbourhood Policy in the Republic of Moldova progress in 2014 and recommendations for actions', <http:// eeas.europa.eu/enp/pdf/2015/repulic-of-moldova-enp-report-2015_en.pdf>, accessed 11 April 2016

European Commission (2015f) 'Implementation of the European Neighbourhood Policy in Ukraine Progress in 2014 and recommendations for actions.' <http://eeas.europa.eu/ enp/pdf/2015/ukraine-enp-report-2015_en.pdf>, accessed 11 April 2016

European External Action Service (2015) 'EU sanctions against Russia over Ukraine crisis', 27 May. <http://europa.eu/newsroom/highlights/special-coverage/eu_sanctions/ index_en.htm>, accessed 11 April 2016

European Parliament (2015) 'European parliament resolution of 11 March 2015 on the 2014 progress report on Serbia (2014/2949(RSP))', <http://www.europarl.europa.eu/sides/ getDoc.do?type=TA\&language $=$ EN\&reference $=$ P8-TA-2015-0065 $>$, accessed 11 April 2016

Farchy, Jack (2014) 'Standoff with west reveals splinters in Putin's Eurasia project', Financial Times, 2 September

Fearon, James and Alexander Wendt (2002) 'Rationalism v. constructivism: a skeptical view' in Walter Carlsnaes, Thomas Risse and Beth A Simmons (eds) Handbook of international relations, 1: 52-72

Foy, Henry (2015) 'Sanctions on Russia: the all-round impact', Financial Times, 14 January, $<$ http://blogs.ft.com/beyond-brics/2015/01/14/sanctions-on-russia-the-all-roundimpact/>, accessed 11 April 2016

Fresh Plaza (2015) 'European produce on Moscow shelves', 10 April, <http://www. freshplaza.com/article/138109/Greek-bypass-for-boycott>, accessed 11 April 2016 
Galtung, Johan (1967) 'On the effects of international economic sanctions, with examples from the case of Rhodesia', World politics, 19:3, 378-416

Gasanova, Madona (2014) 'Georgia speculating on Russia's sanctions', The Financial, 1 September, <http://finchannel.com/index.php/world/georgian-news/item/38761georgia-speculating-on-russia-s-sanctions>, accessed 11 April 2016

Gass, Nick (2016) 'Chris Christie endorses Donald Trump', POLITICO, 26 February, <http:// www.politico.com/story/2016/02/chris-christie-endorses-donald-trump-219861>, accessed 11 April 2016

George, Alexander L (1991) Forceful persuasion: coercive diplomacy as an alternative to war (Washington, DC: United States Institute of Peace Press))

Giragosian, Richard (2014) 'Georgia's EU alignment: regional repercussions', Al Jazeera, 30 June, <http://www.aljazeera.com/indepth/opinion/2014/06/georgia-eu-alignmentregional-2014629123238966304.html>, accessed 11 April 2016

Giumelli, Francesco (2011) Coercing, constraining and signalling: explaining $U N$ and EU sanctions after the Cold War (Colchester: ECPR Press)

Gordon, Joy (1999) 'A peaceful, silent, deadly remedy: the ethics of economic sanctions', Ethics \& International Affairs, 13: 123-142

Gordon, Joy (2002) 'When intent makes all the difference in the world: economic sanctions on Iraq and the accusation of genocide', Yale Human Rights \& Development Law Journal, 5: 57

Gordon, Joy (2010) Invisible war: the United States and the Iraq sanctions (Cambridge, MA; Harvard University Press)

Hall, Rodney Bruce and Friedrich V Kratochwil (1993) 'Medieval tales: neorealist "science" and the abuse of history', International Organization, 47:03, 479-491

Hancock, Kathleen J (2007) 'Russia: great power image versus economic reality', Asian Perspective, 31:4, 71-98

Haukkala, Hiski (2010) The EU-Russia strategic partnership: the limits of post-sovereignty in international relations (London: Routledge)

Hogg, Jonny, and Tulay Karadeniz (2014) 'EU, Turkey need greater alignment to face Islamic state: Mogherini', Reuters, 8 December, <http://www.reuters.com/article/2014/12/08/ usmideast-crisis-eu-turkey-idUSKBN0JM1S820141208>, accessed 11 April 2016

Hovi, Jon, Robert Huseby and Detlef F Sprinz (2005) 'When do (imposed) economic sanctions work?', World Politics, 57:4, 479-499

Hufbauer, Gary Clyde, Jeffrey J Schott and Kimberly Ann Elliott (1990) Economic sanctions reconsidered: history and current policy (Washington, DC: Institute for International Economics)

Hurd, Ian (2010) 'Constructivism', in Christian Reus-Smit and Duncan Snidal (eds.) The Oxford handbook of international relations (Oxford: Oxford University Press), ch. 17

Iceland Monitor (2015) 'Iceland backs further EU Russia sanctions', 21 December, <http:// icelandmonitor.mbl.is/news/news/2015/12/21/iceland_backs_further_eu_russia_ sanctions/>, accessed 11 April 2016 
This is an Accepted Manuscript of an article published by Taylor \& Francis in Cambridge Review of International Affairs on 18 October 2016, available online:

http://www.tandfonline.com/https://doi.org/10.1080/09557571.2016.1230591

Iceland Monitor (2016) 'Minister refuses to back down on Russia', 7 January, <http:// icelandmonitor.mbl.is/news/politics_and_society/2016/01/07/minister_refuses_to_ back_down_on_russia/>, accessed 11 April 2016

Independent Balkan News Agency (2014) 'Albania, sanctions against Russia', 21 March, <http://www.balkaneu.com/albania-sanctions-russia/>, accessed 11 April 2016

Jones, Lee (2015) Societies under siege: exploring how international economic sanctions (do not) work (Oxford: Oxford University Press)

Jones, Seth G (2007) The rise of European security cooperation (Cambridge: Cambridge University Press)

Katzenstein, Peter, Robert Keohane and Stephen Krasner (1998) 'International organization and the study of world politics', International Organization, 52:4, 645-685

Kratochwil, Friedrich (2008) 'Sociological Approaches,' in Christian Reus-Smit and Duncan Snidal (eds) The Oxford handbook of international relations (Oxford: Oxford University Press), ch. 26

Lester, Maya and Michael O’Kane (2016) 'Category: Ukraine', European Sanctions, <https:// europeansanctions.com/category/ukraine/>, accessed 11 April 2016

March, James G and Johan P Olsen (1998) 'The institutional dynamics of international political orders', International Organization, 52:4, 943-969

Marciacq, Florent (2014) 'What does it mean that Serbia refuses to align itself with European sanctions against Russia?', Balkans in Europe Policy Blog, 2 December, <http://www. suedosteuropa.uni-graz.at/biepag/node/125>, accessed 11 April 2016

Marciacq, Florent and Natalia Sanmartín Jaramillo (2015) 'When the European Union speaks on behalf of Non-European Union States: a critical appraisal of the European Union's alignment mechanism in multilateral fora', European Security, 24:2, 203-22. Mayer, Sebastian (2014) 'Common foreign and security policy alignment in the Southern Caucasus', Europe-Asia Studies, 66:10, 1679-1702

Miers, Anne and T Morgan (2002) 'Multilateral sanctions and foreign policy success: can too many cooks spoil the broth?', International Interactions, 28:2, 117-136

Ministry for Foreign Affairs Iceland (2015) 'Government deeply regrets Russia's decision on import ban', <https://www.mfa.is/news-and-publications/nr/8464>, accessed 11 April 2016

Newsweek/Reuters (2014) 'Turkey rebuffs EU criticism on waning foreign policy alignment', 9 December, <http://www.newsweek.com/turkey-rebuffs-eu-criticism- waning-foreignpolicy-alignment-290393>, accessed 11 April 2016

Norman, Laurence (2014) 'EU faces legal worries over Ukraine corruption sanctions', Wall Street Journal, 11 December, <http://www.wsj.com/articles/eu-faces-legal-worries- overukraine-corruption-sanctions-1418305869>, accessed 11 April 2016

Norman, Laurence (2016) 'EU to continue sanctions on some Russians, Ukrainians', Wall Street Journal, 2 March <http://www.wsj.com/articles/eu-to-continue-sanctions-on- somerussians-ukrainians-1456942795>, accessed 11 April 2016

Pape, Robert A (1997) 'Why economic sanctions do not work', International Security, 22:2, 90136 
This is an Accepted Manuscript of an article published by Taylor \& Francis in Cambridge Review of International Affairs on 18 October 2016, available online:

http://www.tandfonline.com/https://doi.org/10.1080/09557571.2016.1230591

Pape, Robert A (1998) 'Why economic sanctions still do not work', International Security, 23:1, 66-77

Passmore, John (1962) 'Explanation in everyday life, in science, and in history', History and Theory, 2:2, 105-123

Portela, Clara (2010) European Union sanctions and foreign policy: when and why do they work? (London: Routledge)

Poznatov, Maja (2014) 'Serbia assures EU it will not exploit Russian food ban', EurActiv, 22 August, <http://www.euractiv.com/sections/enlargement/serbia-assures-eu-it-will- notexploit-russian-food-ban-307929>, accessed 11 April 2016

President of the Republic of Belarus (2014) 'Session to discuss measures to remove ban on import of Belarusian products to Russia', <http://president.gov.by/en/news_ en/printv/session-to-discuss-measures-to-remove-ban-on-import-of-belarusianproducts-to-russia-10334/>, accessed 11 April 2016

President of the Russian Federation (2014) 'Executive order on special economic measures to protect Russia's security', <en.kremlin.ru/events/president/news/46404>, accessed 11 April 2016

Putin, Vladimir (2014) 'Interview to Anadolu agency', President of Russia, 28 November, <http://en.kremlin.ru/events/president/news/47104>, accessed 11 April 2016

Regelsberger, Elfriede (2003) 'The impact of EU enlargement on the CFSP: growing homogeneity of views among the twenty-five', in CFSP Forum (London School of Economics) 1:3, 3-7,

<http://www.lse.ac.uk/internationalRelations/centresandunits/EFPU/EFPUpdfs/CFSPF orum1-3.pdf>, accessed 11 April 2016

Reuters (2014) 'Norway to sign up to EU sanctions against Russia', 30 July, <http:// www.reuters.com/article/2014/07/30/ukraine-crisis-sanctions-norwayidUSL6N0Q54OY20140730>, accessed 11 April 2016

Russell, Martin (2016) 'At a glance: EU-Russia trade', EPRS | European Parliamentary Research Service, <http://www.europarl.europa.eu/thinktank/en/document. html?reference=EPRS_ATA\%282016\%29573931>, accessed 11 April 2016

Schenkkan, Nate (2014) 'Eurasian disunion', Foreign Affairs, 26 December, <https://www. foreignaffairs.com/articles/armenia/2014-12-26/eurasian-disunion>, accessed 11 April 2016

Schimmelfennig, Frank and Ulrich Sedelmeier (2004) 'Governance by conditionality: EU rule transfer to the candidate countries of Central and Eastern Europe', Journal of European public policy, 11:4, 661-679

Sputnik (2016) 'Montenegro's support of Anti-Russian sanctions "Harms bilateral relations", 2 January, <http://sputniknews.com/europe/20160201/1034050824/ montenegrosanctions-russia.html>, accessed 11 April 2016

Sputnik (2014) 'Russia to ban Albanian fruits, vegetables import over re-export from EU', 3 December <http://sputniknews.com/business/20141203/1015460004.html>, accessed 11 April 2016

The Moscow Times (2015) 'Trade war mounts between Kazakhstan and Russia', 13 April, 
<http://www.themoscowtimes.com/business/article/trade-war-mounts-betweenkazakhstan-and-russia/519042.html>, accessed 11 April 2016

The Russian Government (2014) 'On measures to implement the presidential executive order on adopting special economic measures to provide for security of the Russian Federation', <http://government.ru/en/docs/14195/>, accessed 11 April 2016

The Russian Government (2015) 'On expanding the list of countries subject to Russia's retaliatory economic measures', 13 August, <http://government.ru/en/ news/19263/>, accessed 11 April 2016

Thumann, Michael and Özlem Topçu (2015) Türkei: Und Wie Helft Ihr?’ Die Zeit 12, <http:// www.zeit.de/2015/07/tuerkei-aussenminister-pkk-islamischer-staat-ukraine-krise>, accessed 11 April 2016

Törő, Csaba (2010) 'External state partners in ESDP missions: third country participation in EU crisis management', European Foreign Affairs Review, 15:3, 325-345

Tusk, Donald (2015) 'Press statement by President Donald Tusk after his meeting with Prime Minister of Albania Edi Rama', Council of the European Union, <http://www.consilium. europa.eu/en/press/press-releases/2015/02/15021>, accessed 11 April 2016

United Nations General Assembly (2014) 'Official records: sixty-eighth session, 80th plenary meeting', <http://www.un.org/en/ga/search/view_doc.asp?symbol=A/68/ PV.80>, accessed 11 April 2016

Verdens Gang (2014) 'Bred Støtte Til Norske Straffetiltak Mot Russland', 8 November, <http://www.vg.no/a/23272207>, accessed 11 April 2016

White, Nigel and Ademola Abass (2010) 'Countermeasures and sanctions', in Malcolm D Evans (ed) International Law, 3rd ed (Oxford: Oxford University Press), 531-558

Williams, Carol J (2014) 'Russia expands Eurasian Union in competition with European Bloc', Los Angeles Times, 23 December, <http://www.latimes.com/world/europe/la- fg-russiaeurasian-union-versus-europe-20141223-story.html>, accessed 11 April 2016

Yamamoto, Yoshinobu and Stuart A Bremer (1980) 'Wider wars and restless nights: Major power intervention in ongoing war' in David J Singer (ed) The Correlates of War II: Testing Some Realpolitik Models (New York, NY: Free Press), 199-229

Youngs, Richard (2015) 'Armenia as a showcase for the New European Neighborhood Policy?' Carnegie Europe, 2 April, <http://carnegieeurope.eu/strategiceurope/?fa=59617>, accessed 11 April 2016 